DOI https://doi.org/10.36059/978-966-397-113-1/302-321

\title{
PECULIARITIES OF CRIMINAL LIABILITY REGLAMENTATION FOR COERCION TO MARRIAGE ACCORDING THE LEGISLATION OF EUROPEAN COUNTRIES
}

\author{
Syngaivska I. V.
}

\section{INTRODUCTION}

The unification of criminal legislation is the most powerful method of international law influencing on national criminal-law systems. In accordance with Article 9 of the Constitution of Ukraine, the national implementation of legal regulations is possible either by amending the law or direct application in the internal law as a part of the national legislation. Considering defined development vectors Ukrainian criminal and other European states legislation will develop in parallel and increasingly harmoniously and in direction of its further humanization and systematization ${ }^{1}$. Legal literature gives an example of four processes that influence into legislative provision of fighting crime: the globalization of world relations, which also entails negative consequences; significant enlargement of the EU; perception of EU legislation; integration of Ukraine into the $\mathrm{EU}^{2}$. Therefore the comparative legal research of criminal liability regulation is the accumulation of law-making practice experience in counteracting of a particular crime, in our researchcounteracting of coercion to wedlock.

Marriage (as the first family basis) has a special status in the legal field. It has own autonomy with local rules, according to which the interpersonal relationships of the spouses and family members are formed. Marriage and family relationships are characterized by a certain «effect of iceberg», when generally recognized rules and principles of marriage as a model of family relations have a special interpretation in each wedlock; relations are closed, has a covert character, which protects the secret of private and family life.

\footnotetext{
1 Сучасна кримінально-правова система в Україні : реалії та перспективи. Ю.В. Баулін, М.В. Буроменський, В.В.Голіна та ін. К., ВАІTЕ, 2015. С. 468, 484, 548-549 (688 с.)

2 Буроменський М.В., Стешенко В.М. та ін. Розробка пропозицій змін і доповнень до законодавчих актів щодо Державної програми адаптації законодавства України до законодавства Європейського Союзу в галузі боротьби зі злочинністю. Питання боротьби зі злочинністю. Вип.10., Х., 2005. C. $197-200$.
} 
De-facto marriage relations can't have a «two-way symmetry», due to the different functions and roles execution of husband and wife in marriage. However, according to principles of equality between women and men the law requires mutual consent for marriage. The right freely to choose a spouse and to enter into marriage only with their free and full consent. (according to Article 16 Part 1, subparagraph «b»of the The Convention on the Elimination of all Forms of Discrimination Against Women (CEDAW) ${ }^{3}$. The principle of voluntary marriage is valid not only at the stage of its registration, but also during marriage. This leads to the possibility of voluntary dissolution of marriage, according to Article 16 Part 1, subparagraph «c»of the The Convention on the Elimination of all Forms of Discrimination Against Women (CEDAW) «identical rights and duties during marriage and after its dissolution». Marriage is a family union, where the word «family» indicates that marriage creates a family, and the word «union» emphasizes the contractual nature of marriage, which determines its voluntary nature ${ }^{4}$.

Marriage institution of law was formed as a fundamental social institution based on the experience of many generations. In this manner marriage institution is the quintessence of millennial experience of male and female together living (in classical form). Legal regulation of marriage is established with the aim of spouses and children personal and property rights protecting as a guarantees implementation mechanism of fundamental rights and freedoms of citizens. Marriage relations have a basis consisting of customs and traditions, especially regarding the one of the spouse's choice, the process of marriage.

Legal regulation of family relations mainly is carried out through the application of family and civil law rules. Implementation of criminal law for the protection of family relations is carried out in the most socially dangerous manifestations, that is, the commission of a crime.

However, in resolving the issue of criminalization it is important to prevent the revaluation in influence of socio-regulatory capabilities of criminal repression, especially with regard to regulating the sphere of family relations.

\footnotetext{
${ }^{3}$ Про ліквідацію всіх форм дискримінації щодо жінок: Конвенція Організації Об'єднаних Націй. URL https://zakon.rada.gov.ua/laws/show/995_207

4 Рішення Жовтневого районного суду м. Дніпро URL: https://verdictum.ligazakon.net/ document/74424470
} 
Retrospective analysis of criminal legislation states that «forced marriage» is not new thing in the criminal law history. Thus, it was regulated by the Part 11 «Crimes against the rights of the family» of the «Code of Penalties criminal and corrective» of 1845. Chapter 1 «Crimes against marriage union» is an integral part of Part 11, where criminal-law prohibitions of relating to marriage are defined and set forth in 31 criminal articles (from Article 2040 to 2071 of the Code) ) $^{5}$.

Article 2041 of the Code states that «those who, by the use of violence or the use of violence threat, or in circumstances in which a person could or should have considered himself in danger, would compel to enter into a marriage, was punished by exile for hard labor for a term of four to six years». Qualified composition of a crime was recognized «if forced marriage was preceded by the rape of the same person, the perpetrator was sentenced to a higher degree of punishment». At the same time, the differentiation of criminal responsibility for unlawful marriage depended on the method of a socially dangerous act. According to Article 2042 of the Code, if there was a inclining of a person against her/his will into marriage with the help of beverages or otherwise; use of a state of unconsciousness or frenzy or marry by a deceit not with the person who was previously elected, was sentenced to exile in remote Siberia.

Criminal liability is separately provided for a person, who abducted of an unmarried person for marriage against her will was punished by deprivation of all rights and privileges and to exile and imprisonment for a term from two to three years (Article 2040 of the Code). In the case of consent to the kidnapping of an unmarried person, the punishment was imposed in the form of imprisonment from six months to one year. Article 2073 of the Code stipulated that, if married woman was abducted and deprived of honor by the use of violence or otherwise compelled to enter into an illegal marriage with a person who stole her or another person is sentenced to a higher degree of punishment ${ }^{6}$.

Ukraine hasn't ratified the Council of Europe Convention on the Prevention and Combating of Violence against Women and domestic violence; Istanbul Convention (hereinafter referred to as the «Istanbul Convention») yet, but a number of its provisions have been implemented

\footnotetext{
5 Уложеніе о наказаніяхъ уголовныхъ и исправительныхъ 1845 г. Под ред. Н.С. Таганцева. Изд. 5-ге изд. СПб., 1886. С.694

6 Уложеніе о наказаніяхъ уголовныхъ и исправительныхъ 1845 г. Под ред. Н.С. Таганцева. Изд. 5-ге изд. СПб., 1886. С.695-696.
} 
into national law. The implementation of international criminal law rules is possible through incorporation or transformation. Incorporation means almost verbatim implementation of international law into domestic law. During the transformation international criminal law rules are taken into account in domestic law, or to a lesser extent, or vice versa, additional features are added to norms of international criminal law. It is possible a situation, when according to some features the norm of international criminal law narrows and simultaneously on other grounds expands ${ }^{7}$. Implementation through transformation provides an opportunity to take into account the features of national criminal law, thereby preventing an unjustified competition of norms.

Article 37 of Istanbul Convention defines «Forced marriage» and states that parties use all necessary legislative or other measures to ensure that intentional conduct, which is in coercion of adult or a child to marry, has been criminalized.

Parties use all necessary legislative or other measures to ensure that intentional conduct consisting in ensnaring of adult or child to other (other than he or she resides) party territory of or state, to compel this adult or child to marry, was criminalized

In order to implement the provisions of Council of Europe Convention on preventing and combating violence against women and domestic violence of 2011, the forced marriage was criminalized in national criminal law (Article 151-2 of the Criminal Code of Ukraine).

Implementation of Istanbul Convention provisions was reflected in criminal law of foreign countries by its signing and ratification of European states. The content of Istanbul Convention (article 37) emphasizes the criminalization of willful conduct, which is in coercion of adult or child to marry.

The legislative approach of foreign countries in Istanbul Convention realization of concerning the coercive marriage criminalization is an urgent and unexplored issue to which we'll pay attention within the framework of relevant research.

\footnotetext{
${ }^{7}$ Иногамова-Хегай Л.В. Международное уголовное право: учебник. М.: Юридический центр, 2003. C. $42-43$
} 


\section{Basic research material with full basis of received results}

There are two positions of coercion marriage criminalization among foreign countries:

1) countries, which distinguish in criminal law the criminal rule of coercion, without its specification, thus a general norm forming (Finland, Hungary);

2) countries, whose criminal law has criminalized coercion marriage (including those, that have a general rule of involving responsibility for coercion) (Great Britain, Norway, Germany, France, Austria, Switzerland, Sweden, Denmark, Belgium, Spain, Bulgaria, Serbia, Montenegro).

Legal literature notes about the shift of domestic criminal-law policy emphasis, which is manifested in the ever-increasing casualty of the criminal law. Analyzing the question of expediency in coercion marriage criminalizing, A. Andrushko notes that experience of such states as: Austria, Belarus, Bulgaria, Spain, the Netherlands, Poland, Hungary, Germany, Sweden, Switzerland deserves an attention, because its criminal law contains a general rule of involving responsibility for coercion ${ }^{8}$. This fact became an additional argument concerning the need in research of coercion marriage comparative aspect. Comparative legal research of 15 European countries (Western and Eastern Europe) has shown that the dominant majority (13 states) consider expedient to criminalize coercion marriage in a separate criminal norm. Among the list of such states are: Austria, Bulgaria, Spain, the Netherlands, the Federal Republic of Germany, Sweden, Switzerland. Forming of a special rule of criminal liability is a non-rational method of legal technology. At the same time, such forming contributes to realization of criminal law preventive function, which has much more effective impact on understanding of criminal liability law for ordinary citizens.

Criminal prohibition on coercion to certain actions is imposed in criminal law of Finland and Hungary ${ }^{9}$. The Criminal Code of Finland contains Part 8, which defines the responsibility for coercion. The content of the disposition is that, in the case of use of violence or threat of violence, he/she should be punished in the form of fine or imprisonment for a term up to two years. In the Criminal Code of Hungary, the criminal norm «Forcing» is contained in Chapter XVIII «Crimes against personal

\footnotetext{
${ }^{8}$ Андрушко А. Щодо доцільності криміналізації примушування до шлюбу. Jurnalul juridic national: teorie şi practică. 2018. № 6 (34). C. 172

${ }^{9}$ Rikoslaki.URL: www.finlex.fi/fi/laki/ajantasa/1889/18890039001\#L25
} 
freedom». According to its content any person who makes another person with a help of violent or threat of violence to commit or refrain from committing of any acts, that causes significant harm to person's interests and will be find guilty in a grave crime is punished by imprisonment for a period of not more than three years.

In early 2000s only in Norway among other European countries, the law concerning the prohibition of coercion marriage was in force. In following years, the theme of forced marriages, especially among immigrant youth, has become a serious problem and has been actively discussed by European community for the purpose of solving this problem. Many European states consider that adopting of criminal liability law for coercion marriages is one of the effective ways of combating with this problem ${ }^{10}$. There are general rule of coercion (Article 252 Aggravated coercion) and special criminal norm of forced marriage (Section 253 Forced marriage) in Norwegian Criminal Code.

Personal freedom of a person is an object of relevant act, as evidenced by titles of sections containing relevant norm. The corresponding title of sections that contains a separate coercive marriage norm is reflected in Criminal Codes of Norway, Germany, Switzerland, Sweden, Denmark, the Netherlands, Spain, Montenegro and Serbia. The victim is a person without gender and age rating specification. In criminal law of Norway, the objective aspect of the crime is set out in the form of open, alternative list of methods of socially dangerous acts: «unlawful behavior in combination with violence, deprivation of liberty, commission of unlawful pressure force to marry» ${ }^{11}$. Any person who by violence, deprivation of liberty, other criminal or wrongful conductor improper pressure forces a person to enterin to marriage shall be subject to imprisonment for a term not exceeding six years.

The provisions of Istanbul Convention (part 2 article 37) «if, by deception or otherwise, they affect a person to leave the country of residence for the purpose of forced marriage» is contained in foreign legislation of following countries: Norway, Germany, Austria, Sweden, Switzerland, France, Spain, Montenegro and Serbia. So, Part 2 Section 253 "Forced Marriage" of Norway CC contains a provision: The same

\footnotetext{
10 Джансараева Р. Е. Современное уголовное законодательство зарубежных государств об ответственности за ранние и принудительные браки. URL: articlekz.com/article/15034

${ }^{11}$ Lov om straff (straffeloven) URL: https://lovdata.no/dokument/NL/lov/2005-05-20-28/KAPITTEL_29\#\% $2 \%$ A7266
} 
penalty shall be applied to any person who by deceit or other means contributes to another person travelling to a country other than that person's country of residence with the intent that the person will there be subjected to Forced marriage ${ }^{12}$.

The United Kingdom legislation provides that forced marriages can contain physical, psychological, emotional, financial and sexual violence, including illicit captivity, violence and rape ${ }^{13}$. A forced marriage occurs where one or both spouses are forced into marriage without their consent, or where consent is ostensibly given; there has been duress or coercion. Forced marriages are somewhat different to 'arranged marriages' where parents and relatives may help in the selection or choosing of marriage partners, although the ultimate decision to enter into marriage lies with the person/s entering into a marriage contract ${ }^{14}$.

Under the June 2014 reforms, breaches of an FMPO now constitute a breach of the criminal law (although it also retains its civil/family law nature, as FMPOs are issued in the family courts). If the police or the Crown Prosecution Service (CPS) decides to instigate criminal proceedings, a breach of an FMPO can now resultin a term of imprisonment of up to 5 years, although it depends on which route is taken - civil or criminal. Victims who have experienced breaches of FMPOs have dual route stochoose - they can either choose to enforce breaches in either of thecivil or criminal jurisdictions (but not both). The offence of Forced Marriage separately can also result in perpetrators be ingsentenced up to 7 years for forcing a person into marriage (even if there is no FMPO in place). With criminal proceedings, there is the possibility that control will be taken a way from victims - with the police and CPS deciding to go a head with criminal prosecutions, potentially ignoring the wishes of victims. This could lead to cat a strophic consequences, especially if the victim states that they may be harmed or even killed for shaming the family if a prosecution is brought. Then ewlawis complicated by the fact that perpetrators are often family members, including parents and lovedones. While victims may want to escape forced marriages, some may not want to see their mothers or

\footnotetext{
${ }^{12}$ Lov om straff (straffeloven) URL: https://lovdata.no/dokument/NL/lov/2005-05-20-28/KAPITTEL_29\#\% $2 \% \mathrm{~A} 7266$

${ }_{13}^{13}$ Forced marriage now a crime URL: www.gov.uk/government/news/forced-marriage-now-a-crime

14 Maz Idriss The Problem with Forced Marriage Legislation URL: http://www.safelives.org.uk/ practice_blog/problem-forced-marriage-legislation
} 
fathers prosecuted because of the love and emotional attachments involved. Thus, some victims may choose to tolerate forced marriages to avoid parents being prosecuted ${ }^{15}$.

Chapter 237 of Criminal Code of Germany defines the responsibility for coercive marriage with the use of violence or threat of violence ${ }^{16}$. It also provides the responsibility of a person who acts for the purpose of forced marriage with the use of violence, threats of violence or deception associated with moving to a territory or preventing return from there which is not within the scope of FRG Criminal Code.

According to Article 222-14-4 Criminal Code of France, contained in «Chapter II: Attack on the physical or psychological integrity of a person» contains very concise legislative provision, which essentially reflects the provisions of Article 37 of Istanbul Convention: liability in case of coercion the person to enter into marriage or marriage abroad with use of deception in order to leave the person of republic territory ${ }^{17}$. Such a legislative approach is recognized by Montenegro and Serbia.

Chapter 19 of Montenegro Criminal Code, which deals with «Criminal Offenses against Marriage and Family», contains Article 248 «Conclusion on Invalid Marriage». Part 2 of this Article provides the responsibility for coercion to marriage by using violence or threat of violence, in the case of incitement to go abroad for the purpose of forced marriage shall be punishable by imprisonment for a term of three months to three years ${ }^{18}$.

Chapter 19 of Serbia Criminal Code defines crimes against marriage and family in art. 187 «Forced marriage». The relevant article is valid from 01.06.2017 and provides person's responsibility for coercion marriage with violence using or threats of violence Also, the criminal norm provides the liability in the case of facilitating in setting out of foreign country for forced marriage ${ }^{19}$.

The Penitentiary Code of Belgium contains Chapter XI, which deals with responsibility for coercion marriage and forced cohabitation. Belgian criminal law norms of responsibility for coercion marriage and cohabitation are valid from 03.10.2013. Disposition of Article 391 of

\footnotetext{
15 Maz Idriss The Problem with Forced Marriage Legislation URL: http://www.safelives.org.uk/ practice_blog/problem-forced-marriage-legislation

${ }_{16}$ Strafgesetzbuch URL: https://www.gesetze-im-internet.de/stgb/

${ }^{17}$ Code pénal URL:http://codes.droit.org/CodV3/penal.pdf

${ }^{18}$ Кривични законик Црне Горе URL:http://www.mpa.gov.me/biblioteka/zakoni

${ }^{19}$ Кривични законик URL:wipolex.wipo.int/en/text/441512
} 
Belgium PC states, if a person by force or threat of violence has forced a person to marry, there will be a punishment in the form of deprivation of liberty from 3 months to 5 years and a fine of 150 to 5000 Euros. Although Art. 391 regulates the coercion to cohabitation by violence or threat of violence (penalty of 3 to 5 years' imprisonment and a fine of 250 to 5000 Euros). Separately, legislator punishes for attempting to coerce into marriage and cohabitation (from 2 months to 3 years and a fine of 125 up to 2500 Euros $)^{20}$. Consequently, there are identical sentences in the form of liberty deprivation for marriage coercion and forced cohabitation. However, in the case of fine imposition as additional mandatory punishment, it should be noted, that the lower limit of collecting money for coercion cohabitation is higher (250 Euros) in comparison with fine for coercion marriage (150 Euros). Property punishment for the attempt to coercion marriage is determined by a half amount of the main fine.

From 01.01.2016 Austria Criminal Code has a current norm in chapter 106a «Forced marriage». Although Austrian legislator provided separate rules of coercion $(\S 105)$ and severe coercion $(\S 106)$. Article disposition has a details exhaustively list of methods of socially dangerous acts that are emphasized in the content of the research. Thus, Chapter 106a of Austria Criminal Code provides that persons who coerce a person by violence or threat of violence or under the threat of family relationships termination for the purpose of marriage or civil partnership establishment ${ }^{21}$.

Realization of Istanbul Convention prescription of Part 2 Art. 37 in Austria Criminal Code is reflected in following statutory provision: a person who is compelled to marry or to establish civil partnership in a foreign state whose nationality it is not recognized or does not have its habitual residence under the influence of deception or use of violence; or the danger of violence use; or under the threat of termination or dissolution of family contacts with family members, is punishable under paragraph 106 of Austrian Criminal Code. The peculiarity of Austrian legislative concerning responsibility for marriage coercion is in qualified composition determine: "If marriage coercion leads to suicide or to

20 Code pénal de Belgique URL: http://www.ejustice.just.fgov.be/cgi_loi/loi_a1.pl?DETAIL= $1867060801 \% 2 \mathrm{FF} \&$ caller=list \&row_id=1\&numero $=2 \&$ rech $=4 \& \mathrm{cn}=1867060801 \&$ table_name $=$ LOI\& $\mathrm{nm}=186$ $7060850 \& l a=F \& d t=C O D E+P E N A L \&$ language $=f r \& f r=f \& c h o i x 1=E T \& c h o i x 2=E T \&$ fromtab=loi_all\&trier $=$ pro mulgation\&chercher=t\&sql=dt+contains++\%27CODE $\% 27 \% 26+\% 27 \mathrm{PENAL} \% 27$ and + actif $+\% 3 \mathrm{D}+\% 27 \mathrm{Y} \% 27$ $\&$ tri $=\mathrm{dd}+\mathrm{AS}+\mathrm{RANK}+\&$ imgcn.x $=41 \&$ imgen $. \mathrm{y}=12 \# \mathrm{LNK} 0095$

${ }^{21}$ Strafgesetzbuch Republik Österreich URL:https://www.jusline.at/gesetz/stgb/paragraf/106a 
attempt of suicide is punishable by imprisonment for a term of one to ten years»».

For example, Spanish Penal Code contains Chapter III, «Restrictions against Individuals», which include the section «Offenses against Family Relations», which contains a provision that provides a liability for coercion to marriage. Article 172 of this Penal Code was in force from 01.07.2015. It is provide the liability for the threat of violence or violence as a coercion of another person to marriage and the punishment is imposed depending on severity of coercive or means used. The Penal Code of Spain has criminalized the use of violence, threats of violence or deception against a person for the purpose of coercion marriage outside the Spanish territory. There is punishment in form of imprisonment from six months to three years and six months, or a penalty of twelve or twenty four months for relevant acts. A fine will be imposed to the maximum limit in the event of a juvenile coercion ${ }^{22}$.

In Switzerland Criminal Code marriage coercion belongs to felonies and misdemeanors against Liberty. Art.181a of Switzerland Criminal Code states: any person who, by the use of force or the threat of serious detriment or other restriction of another's freedom to act compels another to enter into a marriage or to have a same-sex partnership registered is liable to a custodial sentence not exceeding five years or to a monetary penalty. The same punishment is foreseen for coercion marriage abroad ${ }^{23}$.

In 2014 Part 4 "Crime against freedom and peace" of Criminal Code of the Kingdom of Sweden was supplemented by two rules of coercion marriage in connection with ratification of Istanbul Convention on July 1, 2014. Part 4c stipulates that any person, who illegally compels to marriage that is in force in the state in which it is concluded or in accordance with the law of the state where the marriage was concluded, or in a state in which at least one of the spouses is a citizen, is punished to imprisonment for four years' maximum. This law also applies to a person who forces a person to enter into marriage-like relationship, if it is concluded in accordance with rules according to which the parties are considered as spouses and are given the corresponding rights or duties with respect to each other is punished to imprisonment maximum for four years maximum. Part $4 \mathrm{~d}$ specifies that a person who, by deception, induces

\footnotetext{
${ }^{22}$ del Código Penal URL: https://www.boe.es/buscar/act.php?id=BOE-A-1995-25444

23 Swiss Criminal Code URL: www.legislationline.org/download/action/download/id/7397/file/ Swiss_CC_1937_am2017_en.pdf
} 
another person to travel to state, other than, in which he/she resides for the purpose of unlawful coercion; or use of a vulnerable state for entry into marriage is sentenced to imprisonment maximum for two years ${ }^{24}$.

The introduction of criminal liability for informal and unofficial forms of marriage, that are not legally effective, but in practice are marital, was initiated in Sweden. In addition, the issue of forced marriages is considered together with the problem of «child marriages» of persons under the age of 18. Issues related with the criminalization of children's marriages, which are not legally binding and which are made in accordance with traditions or religious peculiarities of some groups are recognized the most difficult. Organizers and enforcers of coercion marriages should be punished up to 4 years of prison. Parents or guardians, who allowed their children up to 18 to get married or to marry threatens up to 2 years in prison or a fine. According to the Swedish Department of Youth Affairs, more than 70000 people of a country cannot independently choose their spouses ${ }^{25}$.

Article 260 of Chapter 26 «Crimes against Freedom» of Denmark Criminal Code provides the responsibility for coercion. Therewith, Section 2, Art. 260 of Denmark Criminal Code states that in the case of coercion marriage, the terms of imprisonment may be extended to four years $^{26}$.

Article 284 of Netherlands Criminal Code stipulates responsibility for enforcing marriage: «Any person who: 1) illegally forces another person to act or refrain from certain actions or to endure certain acts by resorting of violence or any other act; or threat of violence or threat of other acts against another person or persons; 2) forcing another person to act or refrain from certain actions or to endure certain actions by threatening of slander ${ }^{27}$.

Peculiarities of criminal liability regulation for coercion marriage according to Bulgaria Criminal Code consist in the fact that the legislator differentiates responsibility depending on the types of accomplices of the criminal act and victim's age. Thus, Part 1 of Art. 177 of Bulgaria

\footnotetext{
${ }^{24}$ Criminal code of the Kingdom of Sweden Brottsbalk URL: https://lagen.nu/1962:700\#K4P4cS1

25 Джансараева Р. Е. Современное уголовное законодательство зарубежных государств об ответственности за ранние и принудительные браки URL: articlekz.com/article/15034 Вестник казанского университета 2014 www.euromag.ru/sweden/21915.html

${ }^{26}$ Straffeloven URL: https://www.retsinformation.dk/Forms/R0710.aspx?id=202516\#id484ab143-37b042da-992b-e2e87cf93d9b

${ }^{27}$ Wetboek van Strafrecht URL: https://maxius.nl/wetboek-van-strafrecht
} 
Criminal Code provides: a person who has induced another in compulsory manner to enterin marriage, and therefore the marriage was proclaimed null and void, shall be punished by deprivation of liberty for up to three years. In accordance with Part 2 of Art. 177 of Bulgaria Criminal Code: a person who abducts a person of the female gender for the purpose of forcing her to enterin to marriage, shall be punished by deprivation of liberty for up to three years. If the victim is not of full age, the punishment shall bedeprivation of liberty for up to five years. However, in Art. 178 of the Criminal Code of Bulgaria is determined if a parent or another relative who receives compensation to permit his daughter or relative to conclude a marriage, shall be punished by deprivation of liberty for up to one year or by a fine from one hundred to three hundred BGN(as an equivalent of 1504 to 4514 hryvnias), as well as by public censure. The same punishment shall also be imposed on a person who gives or mediates in the giving or receiving of such compensation ${ }^{28}$.

There are two positions of coercion to marriage singled out in foreign countries legislation:

1) as an attack on personal freedom (Norway, Germany, Switzerland, Sweden, Denmark, the Netherlands, France, Spain, Austria);

2) as an attack on marriage and family relations (Bulgaria, Belgium, Montenegro, Serbia).

The use of violence and threats of violence are typical and alternative methods of coercion to marriage. However, there are some exceptions. Thus, in Austrian CC forced marriage under the threat of breach or termination of family relationships with family members is recognized. In Switzerland criminal law the disposition is formed with an open list of alternative ways of coercion to marriage: «another restriction of freedom action.» The threat of slander and use of direct slander are determined in the Criminal Code of the Netherlands, besides typical and alternative methods of coercion to marriage. According to Article 151 of Ukrainian Criminal Code «coercion» is a crime-forming feature, which is determined by a socially dangerous and unlawful act. Forming a criminal law prohibiting of forced marriage, Ukrainian legislator doesn't follow the list of socially dangerous methods, leaving the interpretation of this issue for law enforcement practice.

\footnotetext{
28 Criminal Code of the Republic of Bulgaria URL: http:legislationline.org/documents/action/ popup/id/8881/preview
} 
In regard to actions related to transfer of a person to another territory for the purpose of forced marriage, the legislation of most states ( 9 out of 15 examined), containing the relevant prescript, provides such methods of coercion as: use of violence, threats of violence and deceit. Swedish legislation is also mentioned the use of person's vulnerability as a method of coercion. Ukraine has also unified the criminal legislation with provisions of Istanbul Convention (Part 2 Article 37), providing the liability for inducement to move to a territory other than that in which it resides for the purpose of coercion to marriage.

According to criminal law of Belgium, Austria, Sweden and Ukraine the responsibility for coercion cohabitation is provided, besides coercion to marry. Switzerland, legislator singles out a special form of coexistence - forced registration to same-sex partnership.

The peculiarity of Ukrainian criminal legislation is the criminalization of coercion to marriage and forced co-habitation. The theory of Ukrainian family law distinguishes following types of cohabitation: actual marriage, guest marriage, open marriage, communal, rational marriage, seasonal marriage, homosexual marriage (same-sex marriage $)^{29}$.

Actual marital relations are not equal with registered marriage. It isn't recognized as marriage at all, because marriage is a family union of woman and man, registered with the state body of civil status acts registration. In accordance with Part 2 Art. 21 of Ukrainian Family Code, living like one family does is not grounds for the appearance of rights and responsibilities of spouses. According to Part 2 Art. 3 of Ukrainian Family Code, the family consists of persons who are jointly living in a common life and have mutual rights and obligations. Living of man and woman like one family does without marriage registration is a special (determined by the law) reason for the establishment of certain rights and obligations. The fact of one family living without marriage registration is confirmed by the common budget, common household and common life, in other words, between partners should formed relationship that is inherent of marriage. Taking into account the relevant provisions, Ukrainian legislator criminalized coercion to cohabitation, besides forced marriage, that is considered to be a reasonable step.

\footnotetext{
${ }^{29}$ Войнаровська О. Фактичні шлюбні відносини як одна із форм співжиття жінки та чоловіка. Юридична Україна. 2015. № 3. С. 45
} 
Issues of punishment for coercion to marriage also have a number of legal and technical features of criminal liability regulation for coercion to marriage.

In regard to issue of punishment for coercion to marriage European legislators have unequivocal position and determine the punishment in the form of imprisonment. There are relatively penal sanctions in the form of imprisonment in countries such as: Norway, Belgium, Austria, Sweden, Bulgaria and Denmark. A number of states have found expedient to form a relatively-defined sanction with a minimum and maximum limit. Among such states are: Germany (from 6 months to 3 years of imprisonment), Austria (from 3 months to 5 years of imprisonment), Belgium (from 3 months to 5 years of imprisonment), Serbia (from 3 months to 3 years of imprisonment), Montenegro (from 6 months to 5 years of imprisonment).

Some states form relatively limited sanctions with only the maximum (upper) limit of punishment: Norway (up to 6 years' imprisonment), Sweden (imprisonment up to 4 years), France (imprisonment up to 3 years), Denmark (imprisonment up to 4 years) and Bulgaria (up to 3 years of imprisonment).

However, according to Austrian Criminal Code, the punishment for coercion to marriage may be up to 10 years' imprisonment if, as results of coercion are serious and lead to suicide or to suicide attempt. In accordance with Part 2 Article 151-2 of Ukrainian Criminal Code, a qualified composition of coercion to marriage in the case of actions committed repeatedly or by a prior conspiracy by a group of persons, or in respect of a person who in accordance with the law has not reached the age of marriage; or in respect of two or more victims, provided punishment by restraint of liberty for a term up to five years or imprisonment for a term up to five years. Also, Part 2 Article 177 of Bulgarian Criminal Code states, if victim has not reached the age of majority, the offender will be sentenced to imprisonment for a term up to five years. Part 3 Art. 172 of Spanish Criminal Code contains that fines are determined according to the maximum limit if the victim is a minor ${ }^{30}$. Separately, Article 216 of Criminal Code of Montenegro provides that adult's living in extra-marital relationship with a minor is punished by

\footnotetext{
${ }^{30}$ del Código Penal URL: https://www.boe.es/buscar/act.php?id=BOE-A-1995-25444/
} 
imprisonment for a term of three months to three years. If marriage is contracted with a minor, the prosecution is not carried out ${ }^{31}$.

Criminal law of foreign countries contains such sanctions that are alternative by their constructive characteristics. For example, in the UK (up to 5 years in prison, in some cases up to 7 years or a fine), the Netherlands (up to 9 months imprisonment or a fine of up to 8200 Euros), Spain (from 6 months to 3 years 6 months or a fine of 20-24 months ), Switzerland (up to 5 years' imprisonment or money collection). Part 4 Section 237 of Criminal Code of Germany is determined that in less socially dangerous cases, a punishment for coercive marriage up to 3 years of imprisonment or a fine may be imposed.

During comparing, it was determined that dominant majority of Europe states formulate relatively precisely defined sanctions as opposed to alternatives, which reflects public danger recognition of a crime and narrowing the discretion regarding the issue of punishment. It is possible to identify two cross-border lines that are observed in determining the maximum term of imprisonment: up to three years and up to five years as the "second line" and deprivation of liberty as maximum term.

There is an alternative sanction for coercion to marriage that provides an arrest of up to 6 months or a restraint of up to 3 years, or imprisonment for up to 3 years in Art. 151-2 of Ukrainian CC. The determined sanction of national legislation compared with legislative experience of other European states is milder, because it provides milder punishments - arrest and restraint of liberty.

The formulation of cumulative sanctions also takes place in legislative practice. Thus, France, in addition to imprisonment, also provides a fine of up to 45,000 Euros that is very strict property restriction. Belgium's criminal law defines punishment from 3 months to 5 years imprisonment and a fine of 150 to 5000 Euros for analyzed crime.

Consequently, a fine as a property penalty should be appointed as alternative or mandatory additional punishment (Germany, France, Switzerland, the Netherlands, Spain, and Belgium). Appropriate legislative experience of foreign countries should be borrowed in order to harmonize of national coercion marriage legislation. We recognize that it is expedient to define a fine as a compulsory additional penalty for coercion, in view of sentencing courts practice. So, taking into account the

${ }^{31}$ Кривични законик Црне Горе URL: http://www.mpa.gov.me/biblioteka/zakoni 
judicial reporting for 2018 , namely p.6 «Report on persons brought to criminal responsibility and types of criminal punishment», 73659 persons are recognized convicts. Among them, the punishment was applied to 55567 persons, and 28096 were released from sentence serving with a trial $^{32}$. The dominant types of punishment are a fine $(19,857$ persons $)$ and imprisonment (13,765 persons). Consequently, number of convicted persons who were released from sentence serving (including those who released from sentence according to Art. 75 of Criminal Code, in connection with amnesty and other reasons) is made up 43\%. In this manner and taking into account that a fine as an additional punishment may be imposed only when it is specifically provided in the sanctions of article (part of article) of Special Part of Criminal Code of Ukraine (Article 53 of CC of Ukraine), this is an argument for the expediency of imposing a fine as an additional form of punishment for coercion to marriage.

Regarding the punishment for inducing a person to move to a territory other than that in which she/he resides for the purpose of forced marriage or cohabitation, which is criminalized in the process of harmonization with Istanbul Convention, the position of legislators is not unanimous. Thus, among states that implemented Article 37 of Istanbul Convention, FRN, France, Spain, Norway, Austria, Switzerland and Ukraine determine the same sanctions for coercive marriage and instigation to move to another territory for the purpose of forced marriage. At the same time, Serbia, Sweden, Montenegro consider the incentive to move to another territory for the purpose of forcing marriage less socially dangerous than coercion, that evidenced by certain sanctions of article. Consequently, Swedish legislator in Chapter $4 \mathrm{~d}$ sets twice less punishment (up to 2 years' imprisonment) for actions involving deception, prompting another person to travel to a state other than that in which he lives for the purpose of illegal coercion or using a vulnerable state to entry into such marriage or marriage partnership. The legislator of Serbia provides maximum sentence of up to 2 years' imprisonment for assistance in traveling abroad for forced marriage. According to Montenegro legislation the incitement to travel abroad for the purpose of forced

\footnotetext{
32 Судова статистика України за 2018 р. № 6 «Звіт про осіб притягнутих до кримінальної відповідальності та види кримінального покарання» URL: https://court.gov.ua/inshe/sudova_ statystyka/rik_2018
} 
marriage, shall be punish by imprisonment for a term of three months to three years.

During comparative legal analysis of European criminal law sanctions, we note that the minimum term of imprisonment at the maximum limit of sanctions for coercion to marriage is provided in Criminal Code of the Netherlands - up to nine months. Legislators of European states do not foresee arrest or restraint of liberty as a sanction for coercive to marriage. There is the most severe punishment in criminal law of Great Britain: The maximum penalty for the new offence of forced marriage is seven years imprisonment ${ }^{33}$.

\section{CONCLUSIONS}

European states in dominant majority determine the coercion to marriage as a separate crime. In this context, national criminal law concerning forced marriage is assessed to be fully consistent with current trends of criminal legal protection rights, individual freedom and marriage and family relations in accordance with the criminal law of foreign countries and international treaties (e.x. Istanbul Convention).

There are two positions of coercion to marriage singled out in foreign countries legislation: as an attack on personal freedom (Norway, Germany, Switzerland, Sweden, Denmark, the Netherlands, France, Spain, Austria) and as an attack on marriage and family relations (Bulgaria, Belgium, Montenegro, Serbia).

According to criminal law of Belgium, Austria, Sweden and Ukraine the responsibility for coercion cohabitation is provided, besides coercion to marry. Switzerland, legislator singles out a special form of coexistence - forced registration to same-sex partnership.

The use of violence and threats of violence are typical and alternative methods of coercion to marriage. However, there are some exceptions as: forced marriage under the threat of breach or termination of family relationships with family members; threat of slander and use of direct slander. According to Article 151 of Ukrainian Criminal Code «coercion» is a crime-forming feature, which is determined by a socially dangerous and unlawful act. Forming a criminal law prohibiting of forced marriage, Ukrainian legislator doesn't follow the list of socially dangerous methods, leaving the interpretation of this issue for law enforcement practice.

\footnotetext{
${ }^{33}$ Forced marriage law sends 'powerful message URL: https://www.bbc.com/news/uk-27830815
} 
In regard to issue of punishment for coercion to marriage European legislators have unequivocal position and determine the punishment in the form of imprisonment.

The provisions of Part 2 Article 37 of Istanbul Convention «if, by deception or otherwise, someone affects a person to leave the country of residence for the purpose of forced marriage» has been transformed into legislation of foreign countries such as: Norway, Germany, Austria, Sweden, Switzerland, France, Spain, Montenegro, and Serbia.

Appropriate legislative experience of foreign countries should be borrowed in order to harmonize of national coercion marriage legislation. We recognize that it is expedient to define a fine as a compulsory additional penalty for coercion, in view of sentencing courts practice.

\section{SUMMARY}

This research is devoted to comparative legal analysis of criminal legislation of Western and Eastern Europe countries and Ukraine concerning the issue of criminal liability for coercion to marriage. The signing and ratification of the Istanbul Convention by European states has led to introduction of legislative amendments aimed at countering coercion to marriage. During the research:

- peculiarities of marriage as a social institution were analyzed;

- differences from other types of cohabitation are determined;

- aspects of historical-legal analysis of criminal responsibility for coercion to marriage were revealed;

- issues of criminal responsibility regulation and punishment of coercion to marriage were disclosed.

\section{REFERENCES}

1. Сучасна кримінально-правова система в Україні : реалії та перспективи. Ю.В. Баулін, М.В. Буроменський, В.В. Голіна та ін. К., BAITE, 2015. $688 \mathrm{c}$.

2. Буроменський М.В., Стешенко В.М. та ін. Розробка пропозицій змін і доповнень до законодавчих актів щодо Державної програми адаптації законодавства України до законодавства Свропейського Союзу в галузі боротьби зі злочинністю. Питання боротьби зі злочинністю. Вип. 10., Х., 2005. С. 197-200. 
3. Про ліквідацію всіх форм дискримінації щодо жінок: Конвенція Організації Об'єднаних Націй. URL https://zakon.rada.gov.ua/ laws/show/995_207

4. Рішення Жовтневого районного суду м. Дніпро URL: https://verdictum.ligazakon.net/document/74424470

5. Уложеніе о наказаніяхъ уголовныхъ и исправительныхъ 1845 г. [Текст]/ Под ред. Н.С. Таганцева . Изд. 5-ге изд.- СПб., 1886. - 898 c. (C.694).

6. Иногамова-Хегай Л.В. Международное уголовное право: учебник. М.: Юридический центр, 2003. 208 с.

7. Андрушко А. Щодо доцільності криміналізації примушування до шлюбу. Jurnalul juridic national: teorie şi practică. 2018. № 6 (34). C. 172 .

8. Rikoslaki.URL: www.finlex.fi/fi/laki/ajantasa/1889/18890039001\# L25

9. Джансараева Р. Е. Современное уголовное законодательство зарубежных государств об ответственности за ранние и принудительные браки. URL: articlekz.com/article/15034

10. Lov om straff (straffeloven) URL: https://lovdata.no/ dokument/NL/lov/2005-05-20-28/KAPITTEL_2-9\#\%C2\%A7266

11. Forced marriage now a crime URL: www.gov.uk/government/ news/forced-marriage-now-a-crime/

12. Maz Idriss The Problem with Forced Marriage Legislation URL: http://www.safelives.org.uk/practice_blog/problem-forced-marriagelegislation

13. Strafgesetzbuch URL: https://www.gesetze-im-internet.de/stgb/

14. Code pénal URL:http://codes.droit.org/CodV3/penal.pdf

15. Кривични законик Црне Горе URL: http://www.mpa.gov.me/ biblioteka/zakoni

16. Кривични законик URL:wipolex.wipo.int/en/text/441512

17. Code pénal de Belgique URL: http://www.ejustice.just.fgov.be/ cgi_loi/loi_a1.pl?DETAIL=1867060801\%2FF\&caller=list\&row_id=1\&n umero $=2 \&$ rech $=4 \& \mathrm{cn}=1867060801 \&$ table_name $=$ LOI $\& \mathrm{~nm}=1867060850$ $\& \mathrm{la}=\mathrm{F} \& \mathrm{dt}=\mathrm{CODE}+\mathrm{PENAL} \&$ language $=\mathrm{fr} \& \mathrm{fr}=\mathrm{f} \& \mathrm{choix} 1=\mathrm{ET} \& \mathrm{choix} 2=\mathrm{ET}$ $\&$ fromtab=loi_all\&trier=promulgation $\&$ chercher $=\mathrm{t} \& \mathrm{sql}=\mathrm{dt}+\mathrm{contains}++\%$ 27CODE $\% 27 \% 26+\% 27 \mathrm{PENAL} \% 27$ and+actif+\%3D+\%27Y\%27\&tri=dd $+\mathrm{AS}+\mathrm{RANK}+\& \operatorname{img} \mathrm{cn} \cdot \mathrm{x}=41 \& \mathrm{img} \mathrm{cn} . \mathrm{y}=12 \# \mathrm{LNK} 0095$ 
18. Strafgesetzbuch Republik Österreich URL: https://www.jusline.at/gesetz/stgb/paragraf/106a

19. del Código Penal URL: https://www.boe.es/buscar/ act.php?id=BOE-A-1995-25444/

20. Swiss Criminal Code URL:www.legislationline.org/download/ action/download/id/7397/file/Swiss_CC_1937_am2017_en.pdf

21. Criminal code of the Kingdom of Sweden Brottsbalk URL: https://lagen.nu/1962:700\#K4P4cS1

22. Straffeloven URL: https://www.retsinformation.dk/Forms/ R0710.aspx?id=202516\#id484ab143-37b0-42da-992b-e2e87cf93d9b

22. Wetboek van Strafrecht. URL: https://maxius.nl/wetboek-vanstrafrecht

23. Criminal Code of the Republic of Bulgaria URL: http:legislationline.org/documents/action/popup/id/8881/preview

24. Войнаровська О. Фактичні шлюбні відносини як одна із форм співжиття жінки та чоловіка. Юридична Украӥна. 2015. № 3. C. $44-54$.

25. Судова статистика України за 2018 р. № 6 «Звіт про осіб притягнутих до кримінальної відповідальності та види кримінального покарання» URL: https://court.gov.ua/inshe/ sudova_statystyka/rik_2018

26. Forced marriage law sends 'powerful message URL: https://www.bbc.com/news/uk-27830815

Information about the author: Syngaivska I. V.

Candidate of Juridical Sciences, Docent, Associate Professor at the Department of Special-Legal Disciplines of the V. I. Vernadsky Taurida National University 33, Ivana Kudri str., Kyiv, 02000, Ukraine 